\title{
In Vitro Cytotoxicity and Apoptosis-inducing Activity of Quercus infectoria Extracts in HeLa Cells
}

\author{
Illyana Ismail', Rapeah Suppian², Habsah Mohamad³ ${ }^{2}$, Siti Aisha Mohd Radzi ${ }^{3}$, Hasmah Abdullah ${ }^{2, *}$
}

Illyana Ismail', Rapeah Suppian², Habsah Mohamad ${ }^{3}$, Siti Aisha Mohd Radzi ${ }^{3}$, Hasmah Abdullah ${ }^{2, *}$

'School of Biomedicine, Faculty of Health Sciences, Universiti Sultan Zainal Abidin Gong Badak Campus, 21300 Kuala Terengganu, Terengganu, MALAYSIA. ${ }^{2}$ Biomedicine Programme, School of Health Sciences, Health Campus, Universiti Sains Malaysia, 16150 Kubang Kerian Kelantan, MALAYSIA.

${ }^{3}$ Institute of Marine Biotechnology, Universiti Malaysia Terengganu, 21300 Kuala Terengganu, Terengganu, MALAYSIA.

\section{Correspondence}

Hasmah Abdullah

Biomedicine Programme, School of Health Sciences, Helath Campus, Universiti Sains Malaysia 16150 Kubang Kerian, Kelantan, MALAYSIA

E-mail: hasmahab@usm.my

History

- Submission Date: 21-12-2020;

- Review completed: 11-01-2021;

- Accepted Date: 22-01-2021.

DOI : 10.5530/pj.2021.13.51

Article Available online http://www.phcogj.com/v13/i2

Copyright

(C) 2021 Phcogj.Com. This is an openaccess article distributed under the terms of the Creative Commons Attribution 4.0 International license.

\section{ABSTRACT}

Background: Quercus infectoria galls (QI) extracts were previously reported to have cytotoxicity effects towards human cervical cancer cells, HeLa. However, the underlying molecular mechanisms of the extracts have been poorly determined. Objective: The present study was undertaken to examine the effect of ethyl acetate extracts of QI (EAQI) on cell cytotoxicity and induction of apoptosis in HeLa cells. Materials and Method: The in vitro cytotoxicity was investigated by using the MTT [3-(4, 5-dimethylthiazol-2-yl)-2, 5-diphenyl tetrazolium bromide] assay and the OD values were read at $570 \mathrm{~nm}$. Meanwhile the induction of apoptosis was measured by using acridine orange and propidium iodide (AO/PI) staining, flow cytometry analysis of annexin V/PI staining and cell cycle distribution. Results: MTT assay showed that EAQI exhibited cytotoxicity effect on HeLa cells with $I C_{50}$ of $11.50 \pm 0.50 \mu \mathrm{g} / \mathrm{ml}$. HeLa cells underwent apoptosis in response to EAQI treatment, demonstrated by an increase in the percentage of apoptotic cell stained with AOPI from $1.00 \%$ to $10.33 \%$ compared to untreated cell population $(p<0.05)$ at 72 hours of treatment. The evidence of early apoptosis in treated cells were also observed in annexin V/PI staining. Furthermore, an increase of cell population in sub G0/G1 phase revealed that apoptosis as the mode of cell death in HeLa cells treated with EAQI. Conclusion: These findings indicated that EAQI significantly inhibits HeLa cell growth through induction of apoptosis. Further studies are needed to confirm the mechanism of cell death by expression of apoptotic cascade in HeLa cells treated with EAQI. Key words: Quercus infectoria, HeLa cells, Cytotoxicity, Apoptosis, Cell cycle.

\section{INTRODUCTION}

Cervical cancer is one of the most common cancers of the reproductive system in women worldwide. Cancer treatments including chemotherapy, radiation and surgery remains the most common treatment for metastatic cancers. ${ }^{1}$ The aim of cancer therapy is to promote the death of cancer cells without harming the normal cells by induction of apoptosis. ${ }^{2}$ Apoptosis induction is one of the most important cytotoxicity markers of antitumor agents. $^{3}$

Apoptosis is a form of programmed cell death characterized by chromatin condensation and nuclear fragmentation (pyknosis), plasma membrane blebbing and cell shrinkage. Eventually, the cells break up into small membrane-surrounded fragments known as apoptotic bodies which are cleared efficiently by phagocytosis without inducing inflammatory response. ${ }^{4}$ However, the increase in resistance as well as adverse effects of radiotherapy and chemotherapy have lead biomedical researchers to investigate novel cancer chemoprevention from herbal resources which could be used for effective treatment of cancer diseases. ${ }^{5,6}$ Many reports have revealed strong evidence that medicinal plant could be a reliable sources for development new therapeutic agents of cancer treatment. ${ }^{7-11}$

Quercus infectoria (QI) is one of the herbal plant that is locally known as "manjakani" in Malaysia and "Majuphal" in Indian traditional medicine. ${ }^{12}$ The QI trees usually grow in Greece and Iran and then spread to Asia Minor, Europe and Northern Africa. ${ }^{13}$ It grows to a height of 4-6 feet with smooth and bright, acorn long, narrow, scaly, and downy leaves. The galls are greyish-brown to brownish-black in colour externally and are yellow internally. It is globular (2 inch), uneven, porous with size of 1.4-2.3 $\mathrm{cm}$ in length and $1-1.5 \mathrm{~cm}$ in diameter. The powder of galls is coarse, creamish brown with no odour but bitter taste. ${ }^{14}$ The gall arise in the branches is resulting from the deposition of eggs by gall wasp Cynips gallae tinctoriae. ${ }^{13}$ The galls have been reported to contain large amount of bioactive constituents such as tannins (50-70\%), small amount of free gallic acid and ellagic acid. ${ }^{5}$ In Malaysia, it has been regularly consumed as herbal beverages to restore postpartum uterine elasticity and also stimulate the contraction of vaginal muscles. ${ }^{16}$ In Indian traditional medicine, it is a constituent of toothpowder or toothpaste for treatment of oral cavity diseases. ${ }^{12}$

Pharmacologically, QI extract has been reported to have antibacterial activity, ${ }^{17}$ antiviral activity ${ }^{18}$ and antifungal activity. ${ }^{19}$ The QI extract also possesses numerous other beneficial functions, including antidiabetic $^{20}$, anti-inflammatory ${ }^{21}$, anti-amoebic ${ }^{22}$ and wound healing. ${ }^{23}$ It was also reported that methanol, ethanol and aqueous extract of QI inhibited the growth of cancer cell lines including HeLa (human cervical cancer cell line $)^{7}$. In addition, ethyl acetate 
extract of QI demonstrated higher cytotoxicity effect towards HeLa cells compared to other solvents extracts. ${ }^{24}$ However, the potential of QI as an anticancer agents and its underlying molecular mechanism still remain to be elucidated yet. Therefore, the current study was designed to evaluate the effect of ethyl acetate extracts of QI (EAQI) on cell cytotoxicity and apoptosis induction in human cervical cancer cell line (HeLa).

\section{MATERIALS AND METHODS}

\section{Preparation of extracts}

QI galls were purchased from Chinese herbal shop in Kota Bharu, Kelantan. The voucher specimen (number: UniSZA 00423) was authenticated by a botanist (Prof Madya Dr Khamsah Suryati Mohd) and was deposited at the Herbarium of Faculty of Bioresoursces and Food Industry, UniSZA. The galls were ground using a grinder to be powder form. About $500 \mathrm{~g}$ of powdered galls were soaked with ethyl acetate $(2.5 \mathrm{~L})$ for 72 hours using shaker at $120 \mathrm{rpm}$ as previously described by Trusheva et al. $(2007)^{25}$. The samples were filtered through whatman no.1 filter paper fitted with a Buchner funnel using suction pressure. The soaking process was repeated for three times. The extracts were evaporated under reduced pressure below $40^{\circ} \mathrm{C}$ to give $90.23 \mathrm{~g}$ of EAQI. The crude extracts were stored at $4^{\circ} \mathrm{C}$ until use. The yield of extracted samples was calculated using the following equation:

Percent of yield extraction $=$ Final weight $(g) \times 100$

\section{Cell culture}

$$
\text { Initial weight }(\mathrm{g})
$$

HeLa (human cervical cancer cells) and Vero (African Green Monkey kidney cells), a type of normal cell line were obtained from the American Type Culture Collection (ATCC, Manassas, VA). Both cells were cultured in Dulbecco's Modified Eagle's Medium (DMEM) (ATCC, Manassas, VA) supplemented with $10 \%$ fetal bovine serum (FBS) and penicillin-streptomycin 1\% (v/v) (Gibco, Grand Island, NY). The cells were incubated at $37^{\circ} \mathrm{C}$ and $5 \% \mathrm{CO}_{2}$ in a humidified atmosphere.

\section{In vitro cytotoxicity assay}

Cytotoxicity activity of EAQI was carried out by using 3-(4,5-dimethylthiazol-2-yl)-2,5-diphenyltetrazolium bromide (MTT) tetrazolium reduction assay. ${ }^{26}$ The EAQI extract was diluted in DMSO (Sigma, St. Louis, MO) to obtain a stock solution of $10.00 \mathrm{mg} / \mathrm{mL}$. Cells $\left(3 \times 10^{4} \mathrm{cells} / \mathrm{mL}\right)$ were treated with various concentration of extract in 96-well culture plates for 72 hours. After 72 hours of treatment, each well was then added with $20 \mu \mathrm{L}$ of MTT solution ( $5 \mathrm{mg} / \mathrm{mL}$ in PBS) and the cells were further incubated for 4 hours at $37^{\circ} \mathrm{C}$. After incubation, the medium was discarded and the insoluble formazan crystals were dissolved by adding $100 \mu \mathrm{L}$ of DMSO. The plates were shaken and the optical density was measured by a microplate reader at $570 \mathrm{~nm}$. (Thermo Scientific Multiskan Spectrum, Thermo Fisher Scientific, Inc., Waltham, MA). The $\mathrm{IC}_{50}$ value of EAQI extract was determined by using non liner regression analysis (percent inhibition versus concentration) and used in subsequent experiments. In this study, cisplatin was used as a positive control.

\section{Cell morphology analysis}

Morphological detection of apoptosis were examined using acridine orange and propidium iodide (AO/PI) staining. ${ }^{27} \mathrm{HeLa}$ cells at a concentration of $5 \times 10^{4} \mathrm{cells} / \mathrm{mL}$ were treated with EAQI for 24,48 and 72 hours at their $\mathrm{IC}_{50}$ concentrations in triplicates. The treated cells were trypsinised and harvested with $1 \mathrm{~mL}$ cold phosphate buffered saline (PBS), followed by centrifuged at $1500 \mathrm{rpm}$ for 10 minutes at $4^{\circ} \mathrm{C}$. This process was repeated twice. The cell suspension was mixed with $20 \mu \mathrm{L}$ of AO/PI solution (1:1) and the mixture $(10 \mathrm{~mL})$ was transferred onto a slide and covered with a cover slip. Viable, apoptotic and necrotic cells were quantified in a population of 200 cells using a fluorescence microscope equipped with B-2A filter (Nikon TE2000-U, Japan). Untreated HeLa cells served as a control negative and cisplatin was used as a positive control.

\section{Determination of phosphatidylserine(PS) externalization}

Annexin V-FITC Apoptosis Detection Kit 1 (Becton Dickinson, USA) was used in determining of phosphatidylserine (PS) externalization. The kit contains Annexin V conjugated to the fluorochrome FITC, propidium iodide and binding buffer. Briefly, HeLa cells ( $5 \times 10^{4} \mathrm{cells} /$ $\mathrm{mL}$ ) were treated with $\mathrm{IC}_{50}$ value of the EAQI extract and cisplatin at 3, 6 and 9 hours. The cells were collected, washed trice with cold PBS and $100 \mu \mathrm{L}$ of binding buffer was added into the tubes. A $3 \mu \mathrm{L}$ of FITC-conjugated Annexin V (Annexin V-FITC) and $3 \mu \mathrm{L}$ of propidium iodide (PI) were then added and incubated at room temperature in the dark for 15 minutes. The stained cells were diluted by the binding buffer $(400 \mu \mathrm{L})$ and immediately analysed with a CytoFlex flowcytometer (Beckman Coulter, USA). About 10000 events were accumulated per sample. The results were generated in a quadrant graph with four different populations of cells represents a viable cells (Annexin V-FITC and PI are negative), early apoptosis (Annexin V-FITC positive and PI are negative), late apoptosis (Annexin V-FITC and PI are positive) and necrosis (Annexin V-FITC negative and PI are positive).

\section{Cell cycle analysis}

Cell cycle analysis was performed according to the protocol in CycleTEST $^{\mathrm{TM}}$ PLUS DNA Reagent Kit (Becton Dickinson, USA). HeLa cells $\left(5 \times 10^{4}\right.$ cells $\left./ \mathrm{mL}\right)$ were cultured overnight in a 6 -well plate and treated with EAQI for 24, 48 and 72 hours at their IC50 concentrations in triplicates. The cells were trypsinised and harvested in a similar manner with AO/PI staining protocol. The cell pellets were resuspended in $250 \mu \mathrm{L}$ of buffer solution A. The cells were then incubated for 10 minutes at room temperature. A $200 \mu \mathrm{L}$ of solution $\mathrm{B}$ was added and the mixture was further incubated for 10 minutes at room temperature. A $200 \mu \mathrm{L}$ of solution $\mathrm{C}$ containing propidium iodide was added and the mixture was incubated in a dark place at $4^{\circ} \mathrm{C}$ for a further 10 minutes. The cellular DNA content was measured by using CytoFlex flowcytometer (Beckman Coulter, USA). Untreated cells were used as a negative control and cells treated with cisplatin were utilized as a positive control.

\section{Statistical analysis}

Results were obtained from three independent experiments. Data were expressed as the mean \pm standard error of the mean (SEM) and analysed by A one-way analysis of variance (ANOVA), followed by Bonferroni post hoc test. The statistical software SPSS (version 22) was used and $\mathrm{p}<0.05$ was defined as statistical significance compared to control.

\section{RESULTS}

\section{Cytotoxic effects of EAQI on the cervical cancer cell lines (HeLa)}

Cytotoxic effect of EAQI extract was tested against HeLa and Vero cells using calorimetric method MTT assay. Cisplatin was used as a positive control drug to compare with EAQI tested against HeLa and Vero cells. Bioactivity of EAQI and cisplatin was determined based on the concentration that induced 50\% inhibition on the growth of the treated cells in triplicate from three independent experiments. EAQI extract and Cisplatin showed toxicity effect towards cancer cell lines and induced significant cell death in HeLa cells with an $\mathrm{IC}_{50}$ value of $11.50 \pm 0.50 \mu \mathrm{g} / \mathrm{mL}$ and $1.85 \pm 0.15 \mu \mathrm{g} / \mathrm{mL}$ respectively at 72 hours of treatment. However treatment of EAQI towards Vero cells exhibited no cytotoxic effect (Figure 1 and Table 1). 
Table 1: IC ${ }_{50}$ of EAQI and cisplatin on HeLa and Vero cells.

\begin{tabular}{ccc}
\hline & $\mathrm{IC}_{50}(\mu \mathrm{g} / \mathrm{mL})$ & \\
& HeLa & Vero \\
\hline EAQI extracts & $11.50 \pm 0.50$ & $>100$ \\
Cisplatin & $1.85 \pm 0.15$ & $14.33 \pm 1.53$ \\
\hline
\end{tabular}

Data are expressed as mean \pm S.E.M from three independent experiments.

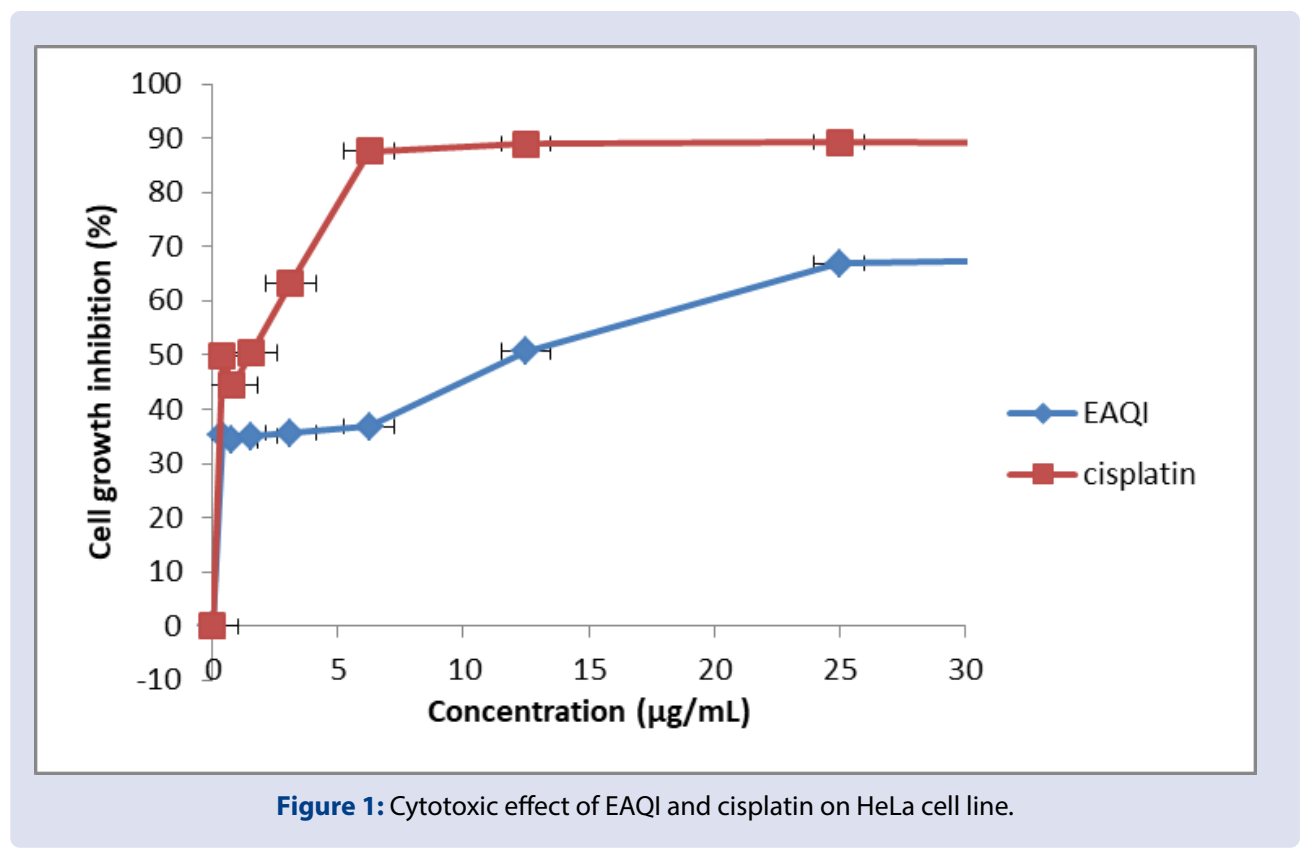

\section{Morphology of apoptosis by AO/PI staining}

$\mathrm{AO} / \mathrm{PI}$ staining was performed to determine the mode of cell death of HeLa cells induced by EAQI and cisplatin. Figure 2 showed that the HeLa cells stained with AO/PI for untreated cells (a), cells treated with $\mathrm{IC}_{50}$ value of EAQI (b) and cells treated with $\mathrm{IC}_{50}$ value of cisplatin (c). Viable cells $(\mathrm{V})$ with intact nucleus structure were stained green. Early apoptotic cells (E) were identified as green, condensed nuclear structure, cell shrinkage and formation of apoptotic bodies. Meanwhile late apoptotic cells $(\mathrm{L})$ have bright orange areas of condensed chromatin in the nucleus and necrotic cells $(\mathrm{N})$ have a uniform red colour. HeLa cells which were treated with EAQI and cisplatin for 24, 48 and 72 hours showed apoptotic event with membrane blebbing, cell shrinkage and the presence of apoptotic bodies compared to untreated (UT) cells. AO/PI analysis also revealed that the percentage of apoptotic cell population in treated cells increased significantly $(\mathrm{p}<0.05)$ in a timedependent manner compared to control (UT). EAQI and cisplatin treatment significantly increased the apoptotic cell population from $0.33 \%$ to $7.67 \%$ (EAQI) and $7.33 \%$ (cisplatin) at 24 hours of treatment. At 48 hours of treatment, a significant increase in the apoptotic cell population was observed from $1.33 \%$ to $8.67 \%$ (EAQI) and $21.33 \%$ (cisplatin). Additionally, at 72 hours of EAQI and cisplatin treatment, the population of apoptotic cell increased from $1.00 \%$ to $10.33 \%$ and $22.67 \%$ respectively compared with the untreated cell population $(\mathrm{p}<0.05)$ (Figure 3).

\section{Phosphatidylserine (PS) externalization and apoptotic induction}

Consistent with the AO/PI staining result, the flowcytometry annexin V/PI analysis demonstrated that apoptosis was induced in a time dependent manner (Figure 4). The plots showing the distribution of HeLa cells within four quadrants that were labelled as Q1 (An-, PI+),
Q2 (An+, PI+), Q3 (An-, PI-) and Q4 (An+, PI-). For the untreated cells, the percentages of viable, early apoptotic, late apoptotic, and necrotic cells were $99.38 \pm 0.15 \%, 0.18 \pm 0.09 \%, 0.14 \pm 0.08 \%$ and $0.25 \pm$ $0.07 \%$, respectively. However, after 3,6 , and 12 hours of treatment with EAQI and cisplatin (CIS), the number of cells increased significantly $(\mathrm{p}<0.05)$ compared to untreated (UT) cells in all three quadrants (Q1, Q2 and Q4) except for Q3. For EAQI treatment, the population of early apoptotic cells $(\mathrm{Q} 4)$ increased to $1.77 \pm 0.06 \%, 1.95 \pm 0.01 \%$, and 2.48 $\pm 0.02 \%$ after 3,6 , and 12 hours, respectively. Similar to early apoptosis, the percentage of late apoptotic cells gradually increased with longer treatment time to $1.54 \pm 0.04 \%, 1.95 \pm 0.01 \%$ and $2.92 \pm 0.03 \%$ cells for 3, 6, and 12 hours, respectively. Meanwhile, the percentage of viable population $(\mathrm{Q} 3)$ for EAQI treated cells decreased significantly $(\mathrm{p}<0.05)$ from $99.38 \pm 0.15 \%$, to $94.53 \pm 0.35 \%, 93.47 \pm 0.12 \%$ and $92.31 \pm 0.21 \%$ after 3,6 , and 12 hours of treatment, respectively. Hence, the overall shift in the population of cells revealed the EAQI capability to cause apoptotic cell death in HeLa cells at the early stage of apoptosis.

\section{Cell cycle analysis}

Cell cycle distribution of HeLa cells treated with $\mathrm{IC}_{50}$ value of EAQI and cisplatin (CIS) at 24, 48 and 72 hours was evaluated by flow cytometric analysis (Figure 5). Results indicated that the sub G0 population in the treated cells (EAQI and cisplatin) were significantly increased $(\mathrm{p}<0.05)$ compared to untreated cells (UT) in a time-dependent manner (Figure 6). At 24 hours treatment of EAQI, the sub G0 population increased from $4.48 \pm 0.06 \%$ to $7.71 \pm 0.17 \%$. After exposure for 48 hours, the sub G0 population increased markedly from $7.75 \pm 0.18 \%$ to $18.79 \pm 0.53 \%$. The sub G0 population increased further from $8.54 \pm 0.11 \%$ to $32.04 \pm$ $0.25 \%$ after 72 hours of EAQI treatment. A similar increased of sub G0 cell population were also observed in cisplatin treated cell. The increase in sub G0 population reveals the induction of apoptosis, as sub G0 peak is reported to be a quantitative apoptosis marker. 


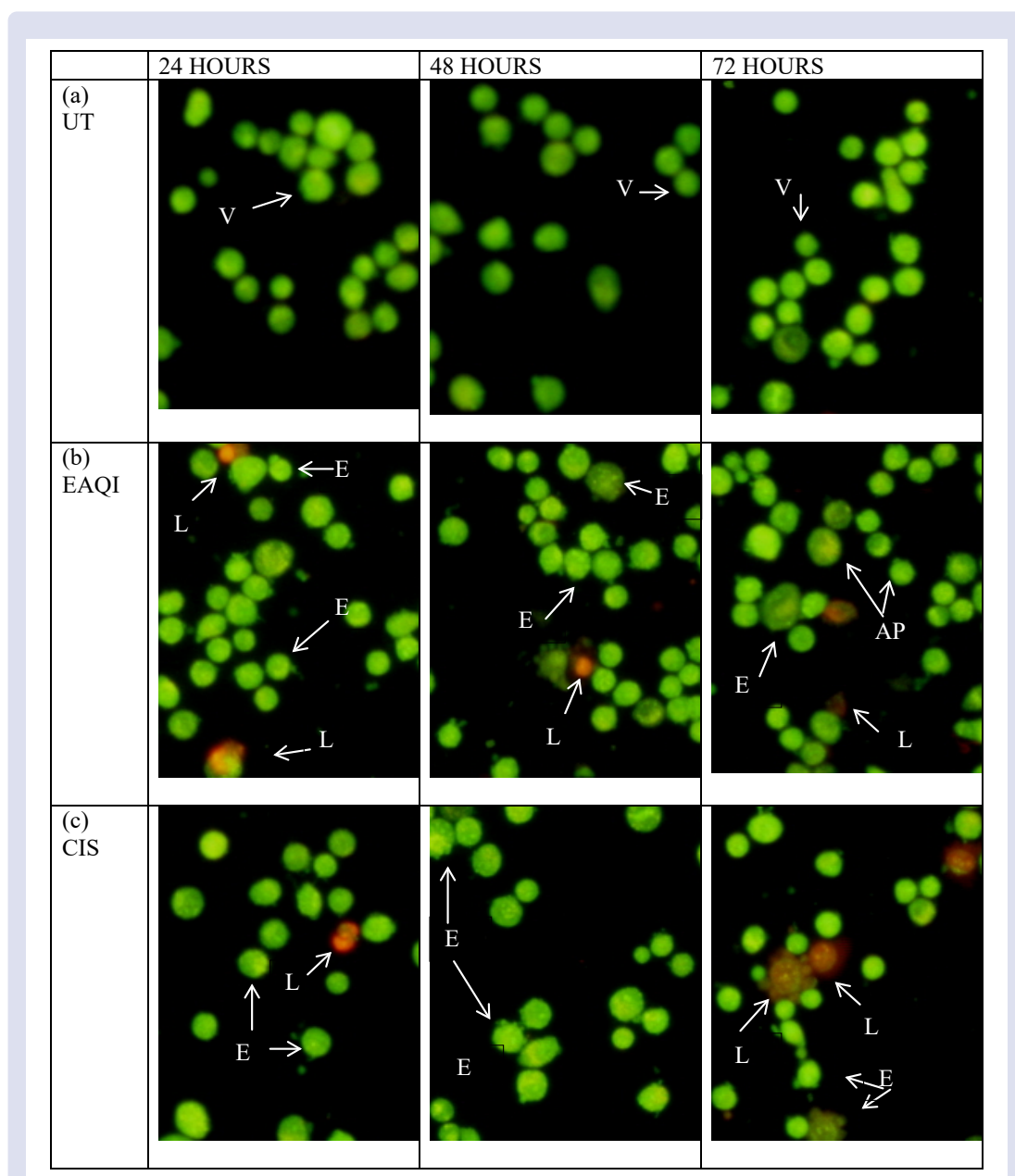

Figure 2: AO/PI staining of HeLa cells were viewed under a fluorescence microscope at 24, 48 and 72 hours. The cells incubated separately as the untreated (a), $11.50 \mu \mathrm{g} / \mathrm{mL}$ EAQl, (b) and $1.85 \mu \mathrm{g} / \mathrm{mL}$ cisplatin, (c). V, viable cell; E, early apoptotic cell; L, late apoptotic cell. The magnification was $100 \mathrm{X}$.

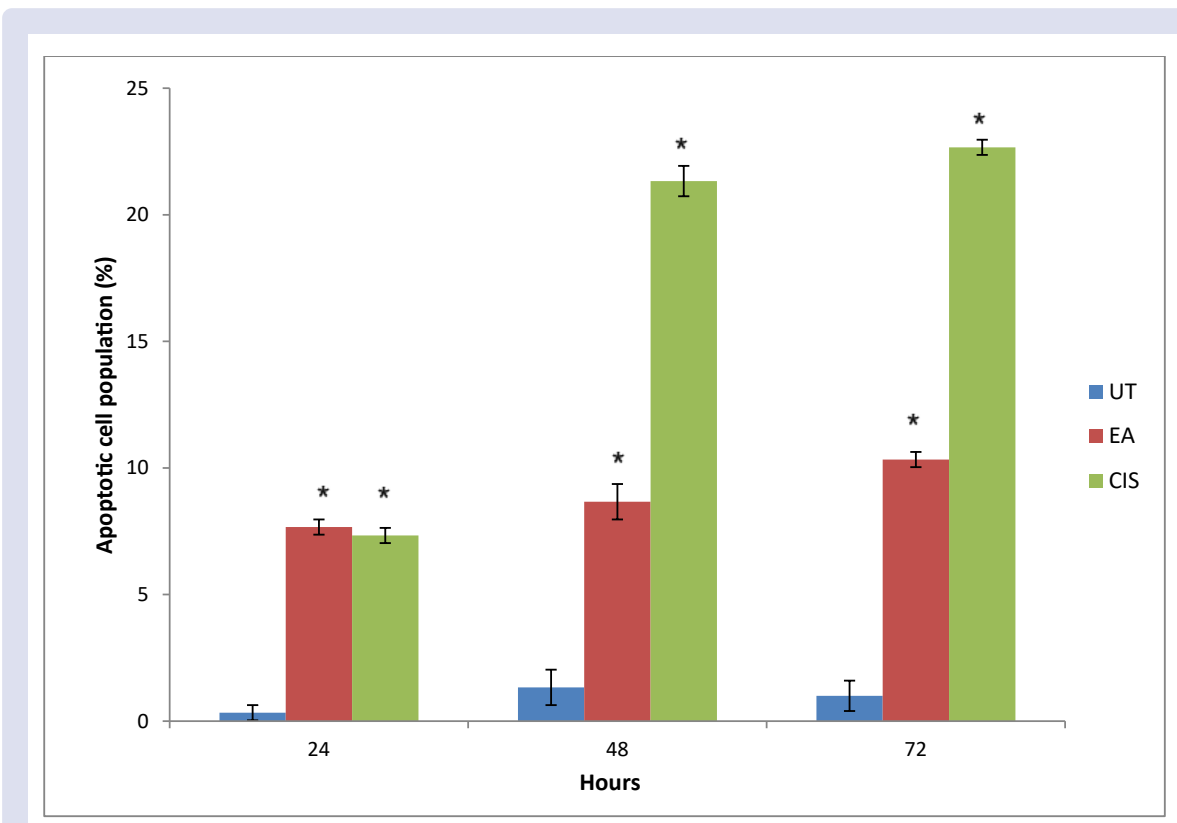

Figure 3: Frequency of apoptotic cell population after treatment with EAQI (EA) and cisplatin (CIS) at 24,48 and 72 hours of treatment. Values are mean \pm S.E.M $(n=3)$. Asterisk $\left(^{*}\right)$ indicates a significant value $(p<0.05)$ as compared with untreated group (UT). 


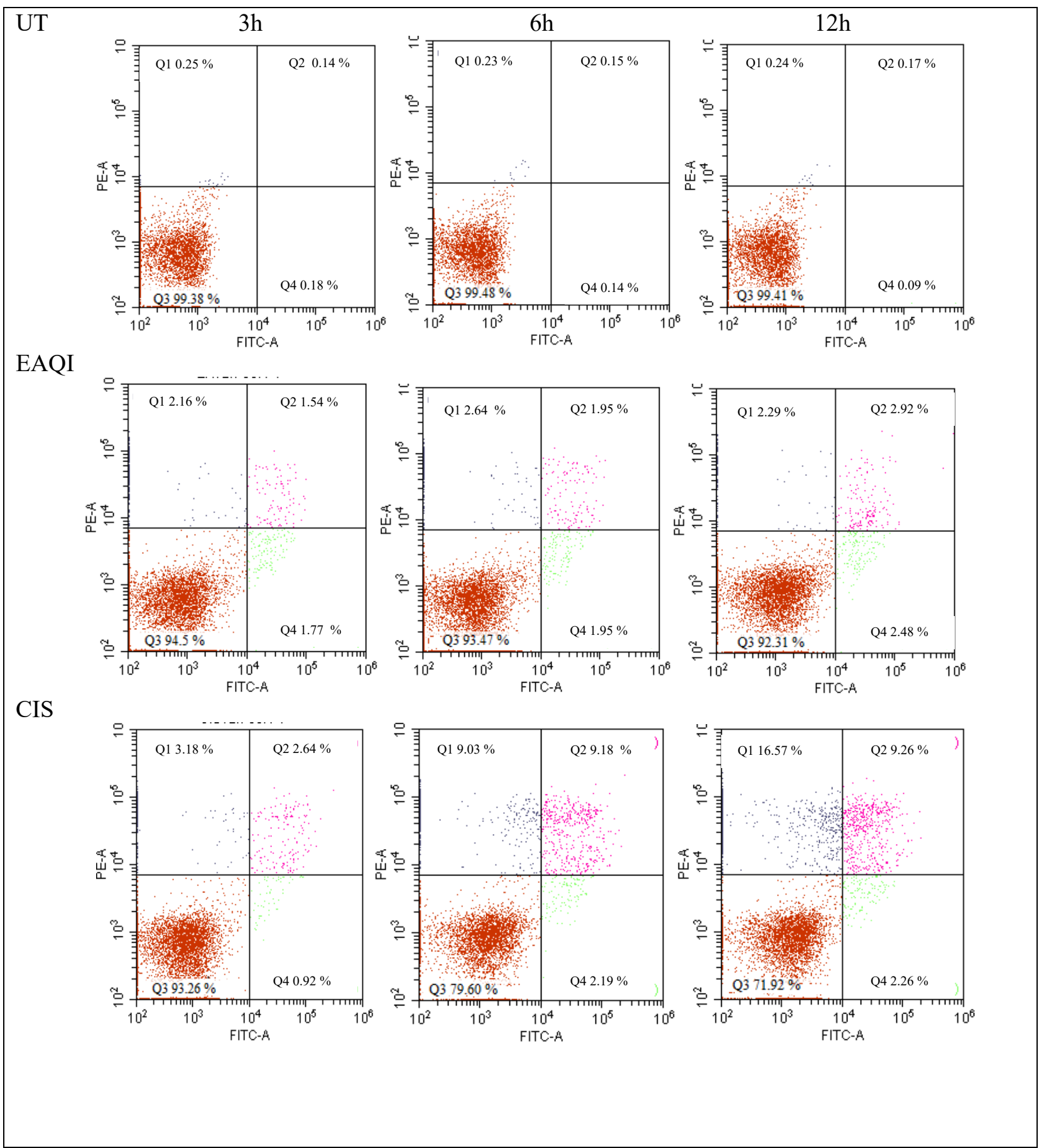

Figure 4: Annexin V(AV) / propidium iodide (PI) staining of HeLa cells treated with EAQI (EA), cisplatin (CIS) as control positive and untreated (UT) group as control negative at 24, 48 and 72 hours of treatment. The $\mathrm{Y}$-axis indicates the PI-labelled population, whereas the X-axis indicates the FITC-labelled Annexin $\mathrm{V}$ positive cells. The lower left quadrant of the fluorocytogram (An-, PI-) shows viable cells (Q3), whereas the lower right quadrant (An+, PI-) shows early apoptotic cells (Q4). The upper right quadrant $(\mathrm{An}+, \mathrm{PI}+)$ shows late apoptotic cells (Q2) and the upper left quadrant $(\mathrm{An}-, \mathrm{PI}+)$ shows the necrotic cells (Q1). 


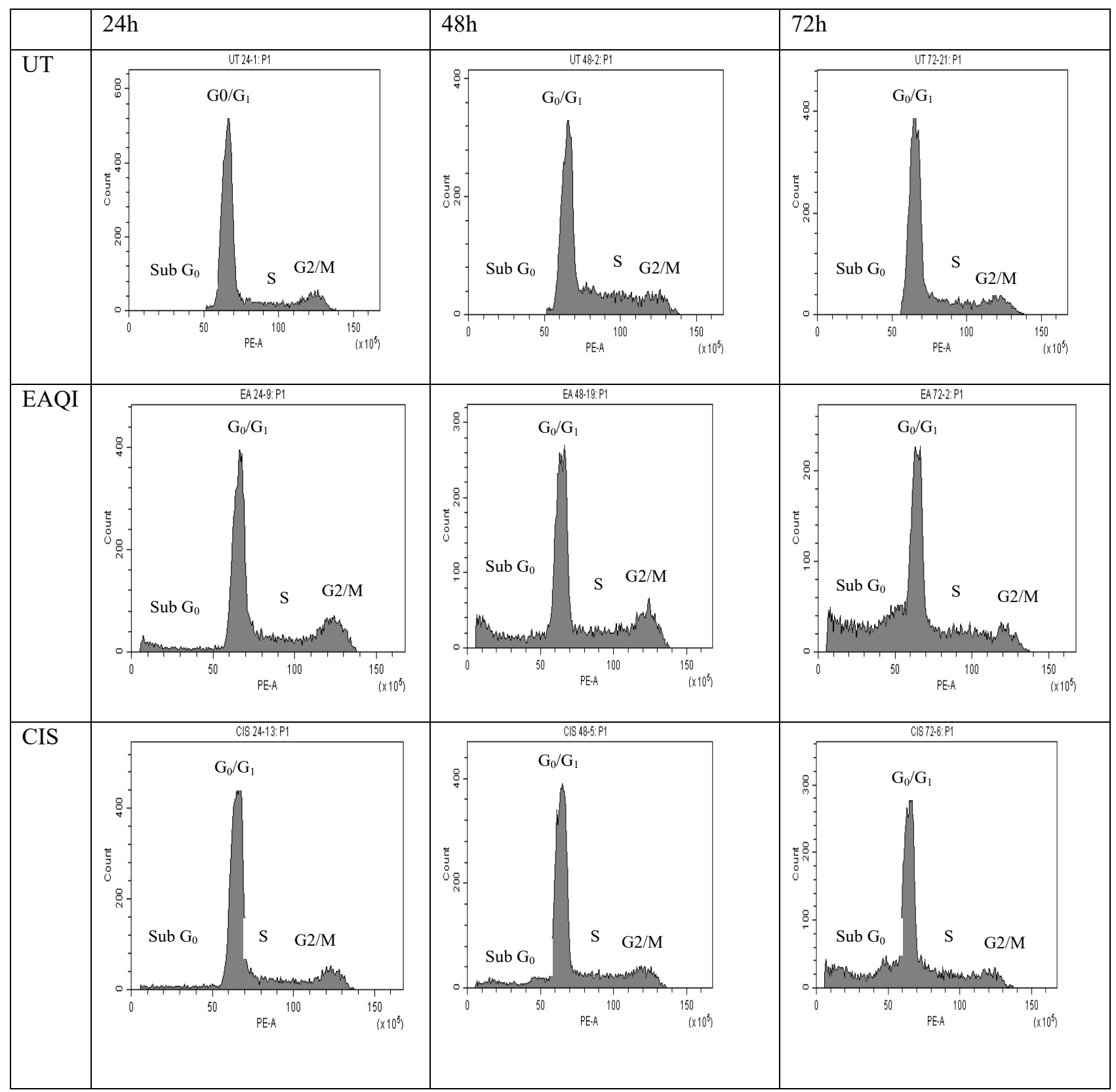

Figure 5: Cell cycle distribution of HeLa cells treated with EAQI, cisplatin (CIS) as control positive and untreated (UT) group as control negative, at 24, 48 and 72 hours of treatment. 


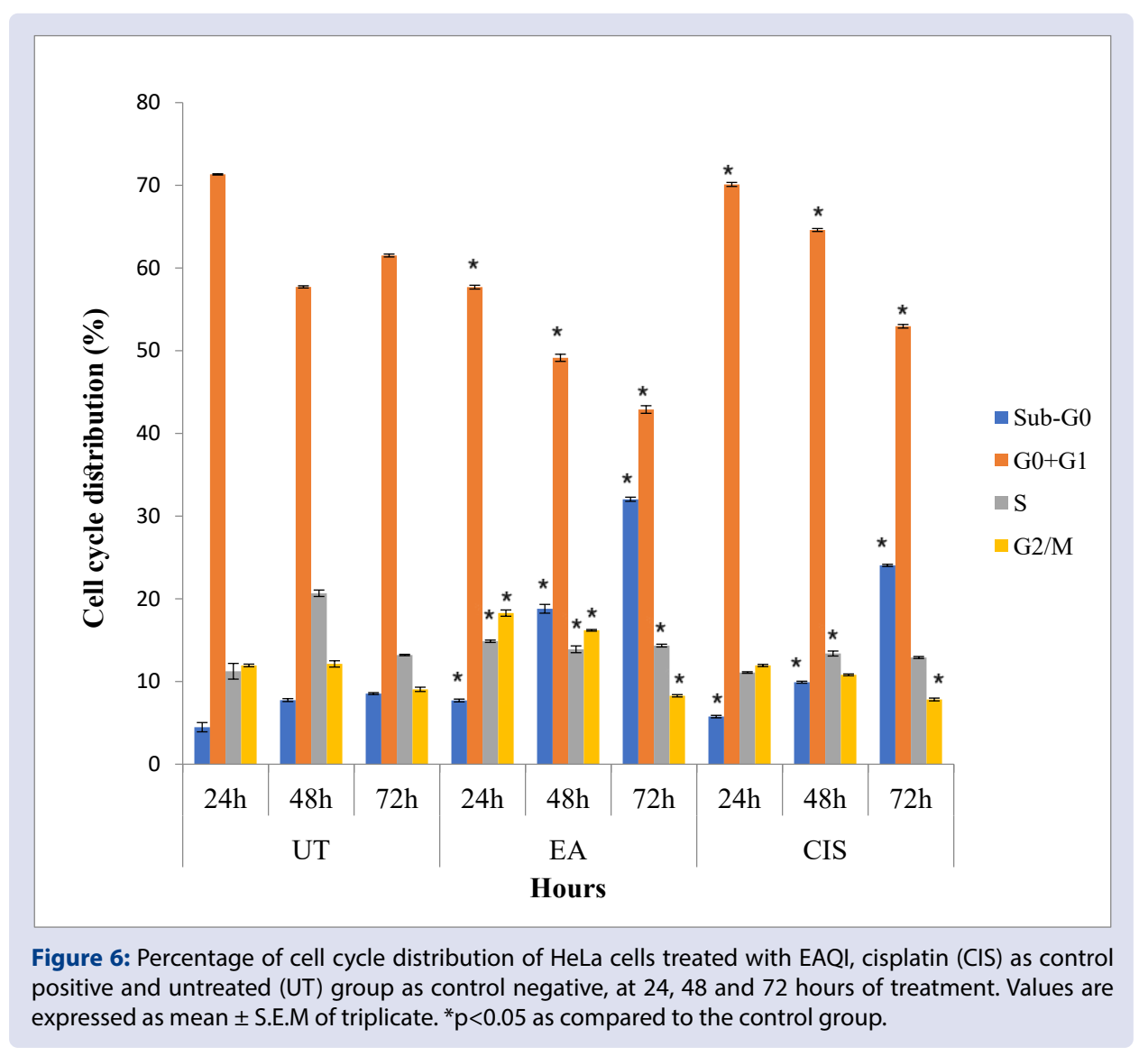

\section{DISCUSSION}

Natural products have been reported to have potent anti-cancer activities and promising candidates as anti-cancer agents. ${ }^{28}$ In Asian, QI has been used as a medicinal plant for years since it was stated to contain large amounts of bioactive compounds. ${ }^{20}$ However, the number of current studies conducted on QI anticancer properties is surprisingly low. The present study was designed to investigate the effects of EAQI on cytotoxicity and to elucidate the mechanism of apoptotic effects in HeLa cells.

This study revealed that ethyl acetate extract of Quercus infectoria (EAQI) showed cytotoxicity effect and caused cell death towards HeLa cell line. According to Umachigi et al. (2008) the antiproliferative activity of Quercus infectoria might be due to the presence of tannins, gallic acid and ellagic acid. ${ }^{23}$ Furthermore, these bioactive compounds have demonstrated to possess anticancer activity on many types of cancer cells ${ }^{29-31}$. On the other hand, EAQI did show the capability to act as a cytoselective anticancer agent since this extract was not cytotoxic to normal kidney epithelial cell line (Vero). Therefore, the effects of EAQI were specific for cancer cells. However, cisplatin, a standard therapeutic drug demonstrated its cytotoxic effect towards both cancer and normal cell lines. The finding from this study were similar to Sakinah et al. (2007) who reported that cisplatin showed potent cytotoxic effect towards normal Chang liver cells and Vero cells line. ${ }^{32}$ Based on MTT assay, EAQI can thus be suggested as a promising cytotoxic agent that might be related to apoptosis induction with cytoselective effect against normal cells.

Apoptosis induction is one of the important approaches in cancer chemotherapy ${ }^{33}$. To determine if the cytotoxicity of extracts involved apoptosis induction treated HeLa cells were analysed using AO/PI staining, determination of phosphatidylserine (PS) externalization and cell cycle analysis. Based on AO/PI staining, the nuclear DNA appears in green fluorescence as $\mathrm{AO}$ passes through the intact cell membrane, while PI emits a red-orange fluorescence in the nucleic DNA of damaged cells. ${ }^{34}$ In this study, after 24 hours of treatment with EAQI and cisplatin, signs of apoptosis in the treated cells were began to be observed. The number of cells undergoing apoptosis (early and late apoptosis) was found to have increased with increasing the treatment duration. The treated cells demonstrated clear morphological changes including loss of cell integrity, cell nuclei fragmentation, cell shrinkage, membrane blebbing and apoptotic body formation compared to untreated cells. These findings are consistent with the study of Wan Yusof \& Abdullah (2020) in which HeLa cells treated with EAQI using Hoechst stain exhibited similar apoptotic events. ${ }^{24}$

A significant feature of chemopreventive agents is the capability to induce cell death through apoptosis rather than necrosis. ${ }^{35}$ During apoptosis process, phosphatidylserine (PS) is translocated and externalized on the outer surface of cell membrane and being accessible for annexin $\mathrm{V}$ binding. Meanwhile the propidium iodide stains late-apoptotic or necrotic cells with impaired cell membrane integrity. ${ }^{10}$ Thus, annexin V-FITC assay was used to further evaluate the apoptotic potential of EAQI. Flow cytometric analysis revealed that EAQI extract induced cell death through early apoptosis induction. Significant increases in the percentages of early and late apoptotic cell populations in $\mathrm{HeLa}$ treated cells without significantly increasing the percentage of necrotic cells were consistent with the results of AO/PI staining assay that showed strong apoptotic morphological changes. Meanwhile, cisplatin incubation of HeLa cells resulted in a significant increase in the number of both apoptotic and necrotic cells. The finding indicated that cisplatin induced cell death through apoptosis and necrosis pathway. ${ }^{36}$

Another significant feature of a potential anticancer agent is its ability to induce cell cycle arrest. The molecular mechanism underlying 
a compound's cytotoxicity can be understood from the cell cycle analysis ${ }^{37}$. Based on the cell cycle analysis, cell cycle arrest at sub G0 was demonstrated in HeLa cells in response to EAQI and cisplatin. Available evidence indicated DNA fragmentation and decreased of DNA content. ${ }^{38}$ Cell death caused by fragmentation of DNA produce apoptotic cells with less DNA than healthy cells, resulting in a sub G0 peak in the cell population profile. ${ }^{39}$ Thus, the increase in sub G0 population in this result indicates apoptosis induction as the sub G0 peak is known as an indication of quantitative apoptosis.

\section{CONCLUSION}

These findings indicate that EAQI significantly inhibits the HeLa cell growth through induction of apoptosis. Further studies are needed to confirm the mechanism of cell death by expression of apoptotic signalling pathway of HeLa cells treated with EAQI.

\section{ACKNOWLEDGEMENTS}

This study was supported by Research University Grant Scheme 1001/ PPSK/ 8012276; RUI from Universiti Sains Malaysia and UniSZA/2017/ DPU/39 by Universiti Sultan Zainal Abidin.

\section{CONFLICTS OF INTEREST}

The authors declare no conflicts of interest.

\section{REFERENCES}

1. Smith HO, Tiffany MF, Qualls CR, Ph D, Key CR. The Rising Incidence of Adenocarcinoma Relative to Squamous Cell Carcinoma of the Uterine Cervix in the United States - A 24-Year Population-Based Study. 2000;105:97-105.

2. Gerl R, Vaux DL. Apoptosis in the development and treatment of cancer. Carcinogenesis. 2005;26(2):263-70.

3. Moradi M taghi, Karimi A, Alidadi S. In vitro antiproliferative and apoptosis-inducing activities of crude ethyle alcohole extract of Quercus brantii L. acorn and subsequent fractions. Chin J Nat Med. 2016;14(3):196-202.

4. Reed JC. Mechanisms of Apoptosis. Am J Pathol. 2000;157(5):141530.

5. Lu Z, Chen $H$, Zheng XM, Chen ML. Experimental study on the apoptosis of cervical cancer Hela cells induced by juglone through c-Jun N-terminal kinase/c-Jun pathway. Asian Pac J Trop Med. 2017;10(6):572-5

6. Khalili RMA, Noratiqah JM, Norhaslinda R, Norhayati AH, Amin BA, Roslan A, et al. Cytotoxicity effect and morphological study of different duku (Lansium domesticum corr.) Extract towards human colorectal adenocarcinoma cells line (HT-29). Pharmacogn J. 2014;9(6):757-61.

7. Hasmah A., Nurazila Z, Chow C, Rina R, Rafiquzzaman M. Cytotoxic Effects of Quercus Infectoria Extracts towards Cervical (Hela) and Ovarian (Caov-3) Cancer Cell Lines. Heal Environ J. 2010;1(2):17-23.

8. Hong J-Y, Chung H-J, Bae SY, Trung TN, Bae K, Lee SK. Induction of Cell Cycle Arrest and Apoptosis by Physcion, an Anthraquinone Isolated From Rhubarb (Rhizomes of Rheum tanguticum), in MDA-MB-231 Human Breast Cancer Cells. J Cancer Prev. 2014;19(4):273-8.

9. Kamatham S, Kumar N, Gudipalli P. Isolation and characterization of gallic acid and methyl gallate from the seed coats of Givotia rottleriformis Griff. and their anti-proliferative effect on human epidermoid carcinoma A431 cells. Toxicol Reports. 2015;2:520-9.

10. Kwan YP, Saito T, Ibrahim D, Al-Hassan FMS, Ein Oon C, Chen Y, et al. Evaluation of the cytotoxicity, cell-cycle arrest, and apoptotic induction by Euphorbia hirta in MCF-7 breast cancer cells. Pharm Biol. 2016;54(7):1223-36.

11. Tajudin TJSA, Mat N, Siti-Aishah AB, Yusran AAM, Alwi A, Ali AM. Cytotoxicity, antiproliferative effects, and apoptosis induction of methanolic extract of cynometra cauliflora linn. Whole fruit on human promyelocytic leukemia HL-60 cells. Evidence-based Complement Altern Med. 2012;2012:1-6.
12. Jain M, Chahar $P$, Jain V, Sharma A, Yadav NR. Role of Quercus infectoria in health and oral health - A Review. Int J Green Pharm. 2019;13(3):180-5.

13. Abdul Haque AS, Ahmad W, Khan RM, Hasan A. Ethnopharmacology of Quercus Infectoria Olivier - Galls: A Review. Hippocratic. Hippocrat J Unani Med. 2016;11(3):105-18.

14. Shrestha S, Kaushik VS, Eshwarappa RSB, Subaramaihha SR, Ramanna LM, Lakkappa DB. Pharmacognostic studies of insect gall of Quercus infectoria Olivier (Fagaceae). Asian Pac J Trop Biomed. 2014;4(1):35-9.

15. Dar, M.S, Ikram, M and Fakouhi T. Pharmacology of Quercus infectoria. J Pharm Sci. 1976;65(12):1791-4.

16. Nur Syukriah AR, Liza MS, Harisun Y, Fadzillah AAM. Effect of solvent extraction on antioxidant and antibacterial activities from quercus infectoria (Manjakani). Int Food Res J. 2014;21(3):1031-7.

17. Basri DF, Tan LS, Shafiei Z, Zin NM. In vitro antibacterial activity of galls of Quercus infectoria Olivier against oral pathogens. Evidencebased Complement Altern Med. 2012;2012.

18. Hussein G, Miyashiro H, Nakamura N, Hattori M, Kakiuchi N, Shimotohno K. Inhibitory effects of Sudanese medicinal plant extracts on hepatitis C virus (HCV) protease. Phyther Res. 2000;14(7):510-6.

19. Baharuddin N, Abdullah H, Abdul Wahab WN. Anti-Candida activity of Quercus infectoria gall extracts against Candida species. J Pharm Bioallied Sci. 2015;7(1):15-20.

20. Hwang JK, Kong TW, Baek NI, Pyun YR. $\alpha$-Glycosidase inhibitory activity of hexagalloylglucose from the galls of Quercus infectoria. Planta Med. 2000;66(3):273-4.

21. Kaur G, Hamid H, Ali A, Alam MS, Athar M. Antiinflammatory evaluation of alcoholic extract of galls of Quercus infectoria. J Ethnopharmacol. 2004;90(2-3):285-92.

22. Sawangjaroen N, Sawangjaroen K, Poonpanang P. Effects of Piper longum fruit, Piper sarmentosum root and Quercus infectoria nut gall on caecal amoebiasis in mice. J Ethnopharmacol. 2004;91(2-3):357-60.

23. Umachigi SP, Jayaveera KN, Ashok Kumar CK, Kumar GS, Vrushabendra swamy BM, Kishore Kumar DV. Studies on Wound Healing Properties of Quercus infectoria. Trop J Pharm Res. 2008;7(1):913-9.

24. Wan Yusof WNS, Abdullah H. Phytochemicals and cytotoxicity of Quercus infectoria ethyl acetate extracts on human cancer cells. Trop Life Sci Res. 2020;31(1):69-84.

25. Trusheva B, Trunkova D, Bankova V. Different extraction methods of biologically active components from propolis; a preliminary study. Chem Cent J. 2007;1(1):1-4.

26. Mosmann T. Rapid colorimetric assay for cellular growth and survival: application to proliferation and cytotoxicity assays. J Immunol Methods. 1983;65:55-63.

27. Ali R, Alabsi AM, Ali AM, Ideris A, Omar AR, Yusoff K, et al. Cytolytic effects and apoptosis induction of newcastle disease virus strain AF2240 on anaplastic astrocytoma brain tumor cell line. Neurochem Res. 2011;36(11):2051-62.

28. T-Johari SAT, Hashim F, Ismail WI, Ali AM. Combinatorial Cytotoxic Effects of Gelam Honey and 5-Fluorouracil against Human Adenocarcinoma Colon Cancer HT-29 Cells in Vitro. Int J Cell Biol. $2019 ; 2019$.

29. Sourani Z, Pourgheysari B, Beshkar P, Shirzad H, Shirzad M. Gallic acid inhibits proliferation and induces apoptosis in lymphoblastic leukemia cell line (C121). Iran J Med Sci. 2016;41(6):525-30.

30. Booth BW, Inskeep BD, Shah H, Park JP, Hay EJ, Burg KJL. Tannic Acid Preferentially Targets Estrogen Receptor-Positive Breast Cancer. Int J Breast Cancer. 2013;2013(1):1-9.

31. Chung YC, Lu LC, Tsai MH, Chen YJ, Chen YY, Yao SP, et al. The inhibitory effect of ellagic acid on cell growth of ovarian carcinoma cells. Evidence-based Complement Altern Med. 2013;2013:1-12.

32. Sakinah SAS, Tri Handayani S, Hawariah LPA. Zerumbone induced apoptosis in liver cancer cells via modulation of Bax/ $\mathrm{Bcl}-2$ ratio. Cancer Cell Int. 2007;7:1-11.

33. Reed JC. Apoptosis-based therapies. Nat Rev Drug Discov. 2002;1(2):111-21. 
34. Khazaei S, Abdul Hamid R, Mohd Esa N, Ramachandran V, Aalam GTF, Etemad A, et al. Promotion of HepG2 cell apoptosis by flower of Allium atroviolaceum and the mechanism of action. BMC Complement Altern Med. 2017;17(1):1-13.

35. Ouyang L, Shi Z, Zhao S, Wang FT, Zhou TT, Liu B, et al. Programmed cell death pathways in cancer: A review of apoptosis, autophagy and programmed necrosis. Cell Prolif. 2012;45(6):487-98.

36. Jakubowicz-Gil J, Paduch R, Ulz Z, Badziul D, Głowniak K, Gawron A. Cell death in Hela cells upon imperatorin and cisplatin treatment. Folia Histochem Cytobiol. 2012;50(3):381-91.
37. Dickson MA, Schwartz GK. Development of cell-cycle inhibitors for cancer therapy. Curr Oncol. 2009;16(2):36-43.

38. Kntayya SB, Ibrahim MD, Ain NM, lori $R$, loannides $C$, Abdull Razis AF. Induction of apoptosis and cytotoxicity by isothiocyanate sulforaphene in human hepatocarcinoma HepG2 cells. Nutrients. 2018;10(6):1-15.

39. Riccardi C, Nicoletti I. Analysis of apoptosis by propidium iodide staining and flow cytometry. Nat Protoc. 2006;1(3):1458-61.

\title{
ABOUT AUTHORS
}

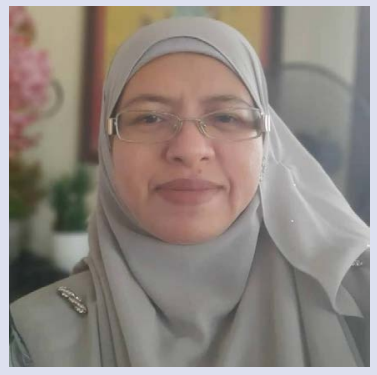

\begin{abstract}
NAME: HASMAH ABDULLAH
CURRENT POSITION: ASSOCIATE PROFESSOR
\end{abstract} ACADEMIC BACKGROUND:

PHD: BIOCHEMISTRY-UNIVERSITI KEBANGSAAN MALAYSIA (UKM)

MASTER OF SCIENCE-BIOLOGY -UNIVERSITI SAINS MALAYSIA (USM)

BACHELOR OF SCIENCE: BIOLOGY (BOTANY)-UNIVERSITI SAINS MALAYSIA (USM)

WORKING EXPERIENCES:

- LECTURER: 2006-2008

- $\quad$ SENIOR LECTURER: 2008-2015

- $\quad$ ASSOCIATE PROFESSOR: 2015-PRESENT

CURRENT RESEARCH: ANTIOXIDANT MECHANISM OF NATURAL PRODUCT IN CANCERTREATMENT IN VITRO

\section{PREVIOUS RESEARCH}

ANTIPROLIFERATIVE MECHANISM OF PLANT DERIVED NATURAL PRODUCT IN CANCERTREATMENT IN VITRO.

MEMBERSHIP IN PROFESIONAL SOCIETIES: MALAYSIAN NATURAL PRODUCT SOCIETY

AWARD RECEIVED:

1. TRAVEL GRANT TO UNIVERSITY OF SZEGED, HUNGARY (2001)

2. SILVER AWARD BIOMALAYSIA EXHIBITION (2010)

3. FUNDAMENTAL RESEARCH GRANT SCHEME, MINISTRY OF EDUCATION 2020

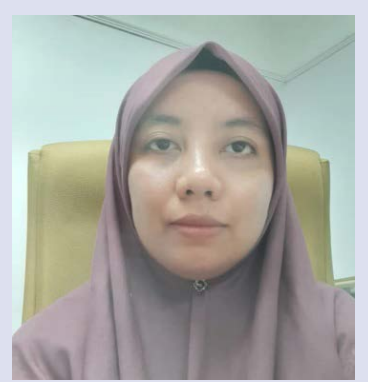

NAME: ILLYANA ISMAIL

\section{CURRENT POSITION: LECTURER}

\section{ACADEMIC BACKGROUND:}

MASTER OF SCIENCE-MEDICAL BIOCHEMISTRY - UNIVERSITI KEBANGSAAN MALAYSIA (UKM) BACHELOR OF SCIENCE: BIOMEDICAL SCIENCES -UNIVERSITI KEBANGSAAN MALAYSIA (UKM) WORKING EXPERIENCES:

SCIENTIFIC OFFICER: 2003-2007

LECTURER: 2007-PRESENT

CURRENT RESEARCH: ANTIPROLIFERATIVE MECHANISM OF NATURAL PRODUCT IN CANCER TREATMENT IN VITRO

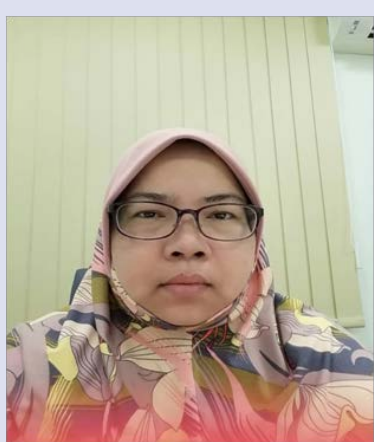

NAME: Associate Professor Dr Habsah Mohamad

CURRENT POSITION: Head of Natural and Synthetic Programme

ACADEMIC BACKGROUND:

PHD: Natural Product Sciences (2003)

BACHELOR OF SCIENCE: BSc (Hons) (1995)

WORKING EXPERIENCES: (1)Tutor, Universiti Kebangsaan Malaysia (1995-1996), Tutor (Universiti Putra Malaysia Terengganu (1997-2003), Lecturer, Universiti Malaysia Terengganu (2003-now)

\section{CURRENT RESEARCH}

Elucidation of the beneficial effects of marine bioactive compounds in atherosclerosis by targeting PCSK9: Harnessing experience-based traditional medicine towards the discovery of evidence - based marine compounds. Sub project 2: Integrated approach and elucidation of marine metabolites in reducing the proression of atherosclerosis via inhibition of PCSK9

Molecular Docking, Synthesis and Biological evaluation of benzamide derivatives towards targeting the inhibitory of PCSK9 gene expression as potential treatment of atherosclerosis.

AWARD RECEIVED

ASEM-DUO France Fellowship Program, Jan 2008, University Malaysia Terengganu and Ministry of Higher Learning, France. 


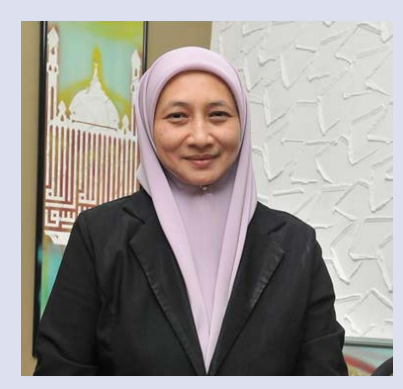

NAME: RAPEAH SUPPIAN

CURRENT POSITION: ASSOCIATE PROFESSOR

ACADEMIC BACKGROUND

PHD: IMMUNOLOGY -UNIVERSITI SAINS MALAYSIA (USM)

BACHELOR OF SCIENCE: APPLIED BIOLOGY-UNIVERSITI SAINS MALAYSIA (USM) WORKING EXPERIENCES:

- LECTURER: 2004-2008

- $\quad$ SENIOR LECTURER: 2008-2015

- $\quad$ ASSOCIATE PROFESSOR: 2015-PRESENT

CURRENT RESEARCH: ROLE OF TOLL LIKE RECEPTOR IN RECOMBINANT BCG VACCINE OR CENTELLA ASIATICA

PREVIOUS RESEARCH: IMMUNOREGULATORY EFFECT OF CENTELLA ASIATICA ON MACROPHAGES AWARD RECEIVED:

1. FUNDAMENTAL RESEARCH GRANT SCHEME, MINISTRY OF EDUCATION 2014

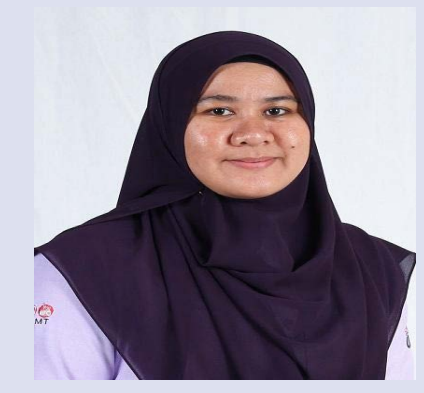

NAME: SITI AISHA BINTI MOHD RADZI

CURRENT POSITION: ASSISTANT SCIENCE OFFICER

ACADEMIC BACKGROUND

Master of Science (Biotechnology), Universiti Malaysia Terengganu (2018)

Bachelor of Science (Hons.) Applied Chemistry, Universiti Teknologi MARA (2008)

WORKING EXPERIENCES

ASSISTANT SCIENTIFIC OFFICER: 2008- PRESENT

PREVIOUS RESEARCH:

Anti-Inflammatory Activities of Compound Isolated from Sponge-Associated Bacteria (2014-2018)

Cite this article: Ismail I, Suppian R, Mohamad H, Radzi SAM, Abdullah H. In Vitro Cytotoxicity and Apoptosis-inducing Activity of Quercus infectoria Extracts in HeLa Cells. Pharmacog J. 2021;13(2): 401-10. 